\title{
Grain quality and associated characteristics and properties of spring wheat of Canadian breeding
}

\author{
Valentina Rubets $^{1}$, Irina Voronchikhina $^{2, *}$, Vladimir Pylnev ${ }^{1}$, Yulia Kotenko $^{1}$, and Andrey \\ Blinkov ${ }^{1}$ \\ ${ }^{1}$ Federal State Budgetary Educational Institution of Higher Education "Russian Timiryazev State \\ Agrarian University", 127550, Moscow, Russian Federation \\ ${ }^{2}$ Federal State Budgetary Institution of Sciences the Main Botanical Garden named after N.V. Tsitsin \\ of Russian Academy of Sciences, 127276, Moscow, Russian Federation
}

\begin{abstract}
The article presents the results of the study of soft spring wheat varieties of Canadian breeding in order to identify the genetic sources of high baking value. A comprehensive assessment of the following economic and useful traits was carried out: yield, plant height, resistance to lodging and major fungal diseases, weight of 1000 grains, grain unit, vitreous content, protein and gluten content in the grain. The method of complex indices was used for the final evaluation of the varieties. It was found that the studied Canadian varieties are unsuitable for use in breeding for high yields in the conditions of the Central part of Russia. It was revealed that the varieties Bluesky, Oslo, Biggar, BW 90, Ac Kagma, CDC Merlin and Ac Taber have the highest values of complex indices. They are recommended for use in the breeding of soft spring wheat varieties with high yield and baking values of grain.
\end{abstract}

\section{Introduction}

Modern breeding is often focused on obtaining high yields of grain crops without taking into account the quality of products. The presence of negative correlations between yield and grain quality has led to the spread of varieties with a high yield of low quality. As a result, in the production of bread and bakery products, technologists are forced to use chemical additives that improve the baking value of low-quality flour $[1,2,3]$.

Nevetheless, in recent years, the number of allergic diseases of the population has been growing, including intolerance to bread containing artificial gluten [3]. This situation can be corrected by creating wheat varieties with high baking value, including in areas of excessive moisture, such as the Central Region of the Non-Chernozem zone of Russia.

Creating varieties of soft spring wheat with a sufficient level of yield with good and excellent baking value is an urgent task.

Soft spring wheat is one of the most common grain crops. It is able to form grain with high baking value, superior to winter wheat. A large amount of protein and gluten is formed

*Corresponding author: yarinkapanfilova@gmail.com 
in the grain of soft wheat, which allows it to be used for baking in its pure form or as an improver $[2,4,5]$. In addition, spring wheat does not depend on winter growing conditions and, with proper care, is able to form a high grain yield.

Based on all of the above, the purpose of this work was to study varieties of soft spring wheat of Canadian origin in order to identify genetic sources of high baking value.

\section{Materials, methods and conditions of research}

The work was carried out at the Russian State Agrarian University - Moscow Agricultural Academy named after K.A. Timiryazev. Field experiments were conducted in 2020 at the Field Experimental Station, laboratory experiments - at the Department of Genetics, Breeding and Seed Production.

The research material was a collection of spring soft wheat varieties of Canadian origin, obtained from the FRC All-Russian Institute of Plant Genetic Resources named after N.I. Vavilov (VIR) (Table 1).

Table 1. Wheat varieties under study

\begin{tabular}{|c|c|c|c|c|c|}
\hline $\begin{array}{c}\text { VIR } \\
\text { catalog } \\
\text { No. }\end{array}$ & $\begin{array}{c}\text { Variety } \\
\text { name }\end{array}$ & Country of origin & $\begin{array}{c}\text { VIR } \\
\text { catalog } \\
\text { No. }\end{array}$ & $\begin{array}{c}\text { Variety } \\
\text { name }\end{array}$ & $\begin{array}{c}\text { Country of } \\
\text { origin }\end{array}$ \\
\hline k-59026 & Katepwa & Canada, Manitoba & k-64448 & Oslo & Canada \\
\hline k-60999 & Laval 19 & Canada, Quebec & k- 64561 & Biggar & $\begin{array}{c}\text { Canada, } \\
\text { Saskatchewan }\end{array}$ \\
\hline k-62599 & Bluesky & Canada, Alberta & k-64150 & BW 90 & Canada \\
\hline k-62600 & Wildcat & Canada, Alberta & k-64596 & $\begin{array}{c}\text { Ac } \\
\text { Barrie }\end{array}$ & $\begin{array}{c}\text { Canada, } \\
\text { Saskatchewan }\end{array}$ \\
\hline k-62853 & Laura & $\begin{array}{c}\text { Canada, } \\
\text { Saskatchewan }\end{array}$ & k-64698 & $\begin{array}{c}\text { Ac } \\
\text { Karma }\end{array}$ & $\begin{array}{c}\text { Canada, } \\
\text { Saskatchewan }\end{array}$ \\
\hline k-49261 & Glenlea & $\begin{array}{c}\text { Canada, Manitoba } \\
\text { k-61227 }\end{array}$ & k-64976 & $\begin{array}{c}\text { CDC } \\
\text { Merlin }\end{array}$ & $\begin{array}{c}\text { Canada, } \\
\text { Saskatchewan }\end{array}$ \\
\hline- & $\begin{array}{c}\text { Canada, } \\
\text { Saskatchewan }\end{array}$ & $\begin{array}{l}\text { k-64699 } \\
\text { (control) } \\
\text { Faber }\end{array}$ & $\begin{array}{c}\text { Canada, } \\
\text { Saskatchewan }\end{array}$ \\
\hline & $\begin{array}{l}\text { "Nemchinovka" } \\
\text { and FSBSI } \\
\text { "Verkhnevolzhsky } \\
\text { FANC" }\end{array}$ & & & & \\
\hline
\end{tabular}

The Zlata variety was used as a standard. This variety is characterized by a complex of economically useful traits that are valuable for the conditions of risky farming, which are characteristic of the Moscow region: early maturity, stunting, resistance to lodging, resistance to major fungal diseases, high grain yield, high baking value.

The precursor of wheat is white mustard for seeds. Agricultural equipment - generally accepted for the zone. In the autumn, plowing was carried out, in the spring - early spring harrowing, application of mineral fertilizers $-\mathrm{N}_{60} \mathrm{P}_{60} \mathrm{~K}_{60}$ r.a./ha, pre-sowing cultivation. The area of the plot is $1 \mathrm{~m}^{2}$, the repetition is three-fold, the placement is systematic. In the phase of the 3rd leaf, a tank mixture of herbicides (Lontrell + Sekator) and insecticide BI-58 were applied, and nitrogen top dressing was added to the tillering phase at a dose of $30 \mathrm{~kg} \mathrm{r}$.a./ha. No other pesticide treatments were carried out before the end of the growing season. Cleaning was carried out manually, sheaf threshing - on a beam-sheaf thresher "MPSU$500 "$. 
During the growing season, the onset of phenological phases was noted, the resistance to lodging was evaluated according to the method of the state variety testing on a 5-point scale, where 1 - complete lodging, 5 - no signs of lodging, intermediate points - depending on the degree of plant stem inclination. Disease resistance - according to the universal 9point VIR scale, in which 1 - a very strong lesion (susceptibility), 9 - no lesion (immunity), $3,5,7$ - different degrees of resistance [6].

The determination of the weight of 1000 grains was carried out according to the accelerated standard method (GOST 12042-80) [7], the grain unit - by micromethod [8], the vitreous - on a diaphanoscope, the amount of protein - on a spectrophotometer "Spektran IT". Gluten was washed according to the standard procedure (GOST 13586.1-68), the gluten quality group was determined on the gluten deformation meter "IDK-3M". The oilcake was obtained at the laboratory mill LMC, and the high-grade flour of $70 \%$ yield was obtained at the laboratory mill "Quadrumat Junior" of the company "Brabender". Laboratory baking was carried out by a semi-macromethod, the recipe - according to the method of state variety testing [9].

Statistical processing of the obtained results was carried out by the method of one-factor variance analysis. The data expressed as a percentage was converted to the angle-arcsine $\sqrt{\text { percent }}[10]$. The significance of the differences in varieties was evaluated taking into account the value of $\operatorname{LSD}_{05}$.

The index method was used for the final evaluation of varieties based on a set of characteristics [11].

The growing season of 2020 in the Moscow region as a whole was characterized by a moderate temperature regime, close to the average long-term values, an early spring April drought, excessive moisture in May - July, and a relatively dry August (Fig. 1). In April May, the air temperature was generally slightly lower than the long-term average values, in June - exceeded them by about $1-4^{\circ} \mathrm{C}$, in the second and third decades of July and August close to the long-term average values.

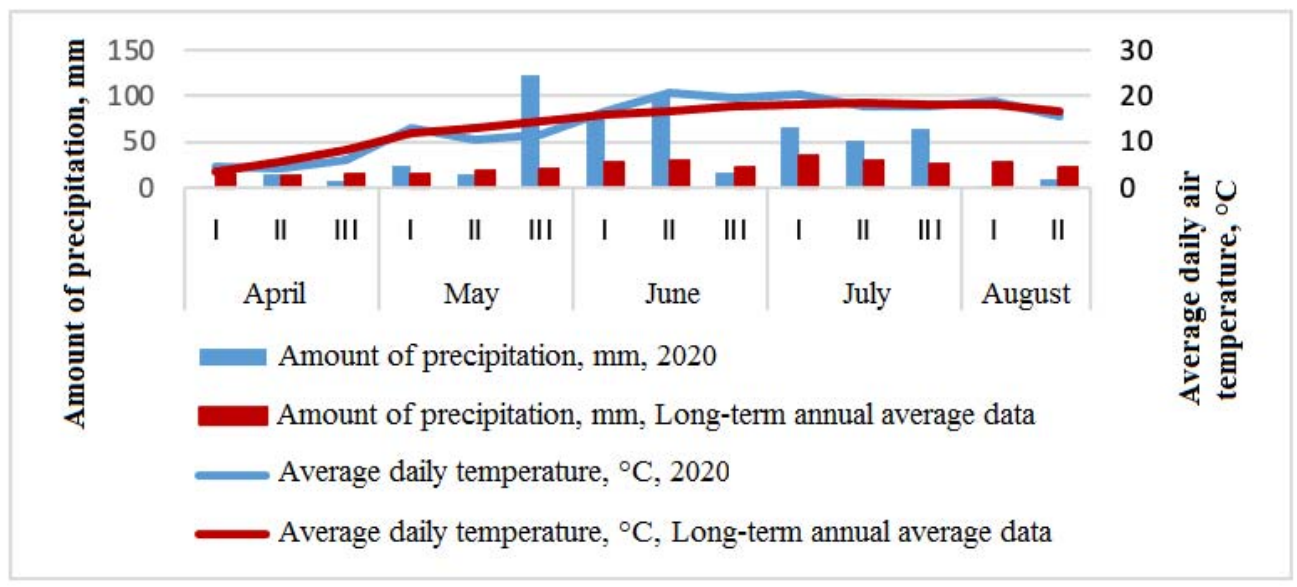

Fig. 1. Meteorological conditions of vegetation, 2020 (according to the data of the Meteorological Observatory n.a. V.A. Michelson)

In the first and second decades of May, the humidification conditions corresponded to the zone, then in the third decade, the amount of precipitation exceeded the average annual values by more than 6 times, in the first and second decades of June - by more than 3 times, in July - by almost 2 times. Only in August, heavy rains stopped, which made it possible to harvest wheat in time. 


\section{Results and discussion}

Meteorological conditions, during the experiment, contributed to the manifestation of the potential of spring wheat genotypes. The plant development at the beginning of the growing season took place in favorable conditions of moderate temperature and sufficient moisture, which contributed to friendly shoots and good tillering. In the phase of leaf-tube formation beginning (the third decade of May), the low temperature and excess precipitation increased the duration of the phase, which eventually led to the development of a thick vegetative mass of wheat plants. The studied varieties showed the potential of height and resistance to lodging. Flowering took place in relatively favorable conditions of sufficient moisture against the background of slightly elevated temperatures (the third decade of June). Grain formation and filling (the first and second decades of July) took place in conditions of moderate temperatures and excess precipitation, which contributed to the development of large grain crops. Excess precipitation against the background of low temperature accompanied the beginning of wheat grain maturation (the third decade of July), dry moderate weather (the first decade of August) - the end of maturation.

In the conditions of the Central region of the Non-Chernozem zone, grain harvesting often coincides with the rainfall. Therefore, for the successful cultivation of spring wheat, it is necessary to create varieties with a short or medium growing season.

The studied varieties were early-maturing, the phases of their development almost coincided with the early-maturing Zlata standard. The shortest growing season was characterized by the varieties Oslo, Biggar, Ac Barrie, Ac Kagma, which is relevant for the zone of risky agriculture $[12,13]$.

The wheat plants of all the studied varieties did not exceed the Zlata standard in height (Table 2). Most of the studied Canadian wheat varieties did not reach $100 \mathrm{~cm}$ (the optimal height for the middle zone of Russia). And at the same time, most of the varieties died. Especially strong and early lodging was noted in the Leader variety.

Table 2. Yield, height, and disease resistance of spring wheat varieties included in the 2020 study collection

\begin{tabular}{|c|c|c|c|c|c|c|c|}
\hline \multirow[b]{2}{*}{ Variety } & \multicolumn{2}{|c|}{ Yield, } & \multirow[b]{2}{*}{$\begin{array}{l}\text { Plant } \\
\text { height, } \\
\mathrm{cm}\end{array}$} & \multicolumn{4}{|c|}{ Resistance, score } \\
\hline & $\mathrm{g} / \mathrm{m}^{2}$ & $\begin{array}{c}\text { as a } \\
\text { percentage } \\
\text { of the } \\
\text { standard }\end{array}$ & & lodging & leaf rust & $\begin{array}{c}\text { powder } \\
\mathrm{y} \\
\text { mildew }\end{array}$ & $\begin{array}{l}\text { fusarium } \\
\text { head } \\
\text { blight }\end{array}$ \\
\hline Katepwa & 428.8 & 83 & 105 & 5 & 9 & 3 & 3 \\
\hline Laval 19 & 463.0 & 89 & 85 & 5 & 7 & 3 & 4 \\
\hline Bluesky & 425.6 & 82 & 105 & 3 & 9 & 9 & 3 \\
\hline Wildcat & 398.4 & 77 & 100 & 5 & 9 & 1 & 3 \\
\hline Laura & 373.2 & 72 & 105 & 2 & 9 & 7 & 3 \\
\hline Glenlea & 391.2 & 75 & 110 & 3 & 7 & 7 & 3 \\
\hline Leader & 243.4 & 47 & 100 & 1 & 9 & 9 & 3 \\
\hline Zlata & 519.1 & 100 & 110 & 4 & 7 & 7 & 4 \\
\hline Oslo & 332.3 & 64 & 75 & 5 & 9 & 5 & 5 \\
\hline Biggar & 458.8 & 88 & 80 & 4 & 7 & 9 & 5 \\
\hline BW 90 & 479.4 & 92 & 110 & 3 & 7 & 9 & 5 \\
\hline Ac Barrie & 396.9 & 76 & 95 & 5 & 3 & 3 & 5 \\
\hline Ac Karma & 515.0 & 99 & 90 & 3 & 7 & 9 & 3 \\
\hline $\begin{array}{l}\text { CDC } \\
\text { Merlin }\end{array}$ & 438.0 & 84 & 95 & 3 & 9 & 5 & 5 \\
\hline Ac Taber & 495.0 & 95 & 85 & 5 & 7 & 7 & 3 \\
\hline $\mathrm{LSD}_{05}$ & 79.7 & - & - & - & - & - & - \\
\hline
\end{tabular}


Thus, in this set of varieties, the main condition for resistance to lodging is not the height, but the strength of the stem. No signs of lodging were found in the varieties Katepwa, Laval 19, Wildcat, Oslo, Ac Barrie, Ac Taber. The importance of the source material as a donor of a short strong stem is confirmed by many researchers $[14,15,16]$.

In the zone of excessive moisture, an important advantage of the varieties is their resistance to the main fungal diseases - leaf rust (Puccinia recondita), powdery mildew (Erysiphe graminis), fusarium head blight (Fusarium sp.). In 2020, excess moisture and high air temperature contributed to the rapid development of pathogenic microbiota in grain crops, forming a natural infectious background. The natural and climatic conditions of Canada are similar to those of Central Russia, but with a large geographical distance, the racial composition of the pathogenic microbiota cannot be the same. Therefore, the assessment of the resistance of the source material to local races of major fungal diseases is important for further use in the breeding process. According to the results of observations, almost all varieties of the Canadian collection showed high resistance to local races of brown rust (except for the Ac Barrie variety) (Table 2). However, most were affected by powdery mildew to varying degrees. The maximum stability was achieved by the varieties Bluesky, Laura, Glenlea, Leader, Biggar, BW 90, Ac Kagma, Ac Taber. All the varieties without exception, even the standard Zlata, were struck by the fusarium head blight to varying degrees. The average degree of resistance to fusarium was noted in the varieties Oslo, Biggar, BW 90, Ac Barrie, CDC Merlin. The rest - below average.

Summing up, we can distinguish the varieties Oslo, Biggar and Ac Taber, which are characterized by complex resistance to lodging and major fungal diseases in Central Russia. The value of the source material with high resistance to diseases is recognized by the majority of practicing breeders [12, 15, 17].

The main integral indicator of the variety adaptability is its yield. The conditions of the year contributed to the formation of the maximum yield. Nevertheless, the yield of all varieties of the Canadian collection did not reach the level of the standard - Zlata. The lowest yield was obtained for the Leader variety ( $47 \%$ to the standard), despite its low stem and almost immunity to brown rust and powdery mildew. The variety lodged to the maximum among all (1 point), which probably contributed to the enzyme-mycotic depletion, which is indirectly evidenced by the low weight of 1000 grains (Table 3). Some varieties - Laval 19, Biggar, BW 90, Ac Kagma, Ac Taber - were unreliably different from the standard in terms of yield. Their yield was $88-99 \%$ of the standard.

Thus, the test of Canadian varieties in the conditions of the Middle zone of Russia showed their unsuitability for breeding for increased grain yield. However, it is known that the material from other district can be used as a paternal form for the introduction of useful traits [15].

The wheat grain quality is considered in two aspects - its nutritional value, which depends on the protein content and its components, and its technological properties, which characterize the grain suitability for the production of flour and bread [5]. Physical properties of the grain (weight of 1000 grains, unit, vitreousity) indirectly determine the milling and baking qualities [12].

The weight of 1000 grains is determined by the grain size and the endosperm plumpness. For the studied set of varieties, this indicator has a significant positive correlation with grain yield and a negative one with the protein content in it (Fig. 2). The studied varieties of spring wheat were characterized by a high weight of 1000 grains, with the exception of the Laura and Leader varieties (Table 3). The indicated varieties greatly lodged and were struck by fusarium head blight. Obviously, there was an enzyme-mycotic depletion of the grain. The largest grain size was characterized by the varieties Bluesky, Wildcat, Glenlea, Zlata and Ac Taber. 
The grain unit characterizes the degree of endosperm plumpness [12]. Almost all the studied wheat varieties showed high values of grain unit and did not differ significantly from each other (Table 3). Only in the varieties Laval 19 and Oslo, the values of unit are reduced.

Vitreousity in soft wheat is a varietal trait, but the prevailing meteorological conditions can affect the degree of indicator manifestation [5]. Flour endosperm was formed in the violet-colored variety Laval 19 (Table 3). The remaining varieties formed a high-vitreous endosperm, which indirectly testifies in favor of flour with good baking value $[17,18]$.

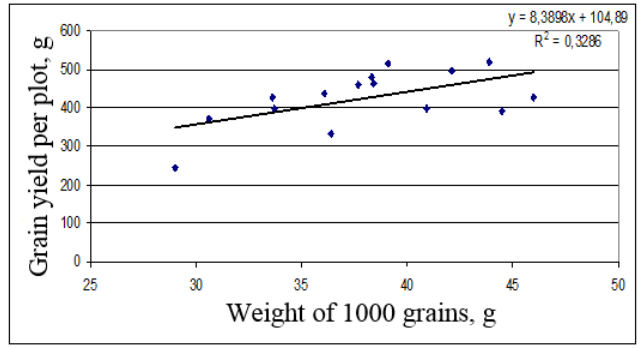

a

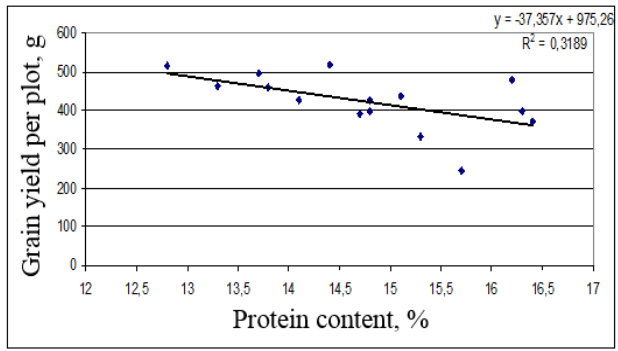

b

Fig. 2. Relationship between yield, weight of 1000 grain (a) and protein content (b) of Canadian spring wheat varieties

The protein and gluten content characterizes both the nutritional value of wheat grain, and its suitability for obtaining high-quality bread. Most of the studied varieties contained high amounts of protein and gluten (Table 3). The gluten had a light cream color, formed into an elastic ball with plastic strands. Only the gluten of the Laval 19 variety, due to the purple color of the grain, had a dark purple color with a metallic shine. According to baking value, Canadian varieties were divided into groups according to the content of protein, gluten and their quality group according to the GDI.

Table 3. Grain quality indicators of spring wheat varieties

\begin{tabular}{|c|c|c|c|c|c|c|c|c|}
\hline & \multirow{2}{*}{$\begin{array}{c}\text { Weight } \\
\text { Variety } 1000 \\
\text { grains, } \\
\mathrm{g}\end{array}$} & \multirow{2}{*}{$\begin{array}{c}\text { Unit, } \\
\mathrm{g} / \mathrm{l}\end{array}$} & $\begin{array}{c}\text { Common } \\
\text { vitreosity, } \\
\%\end{array}$ & \multicolumn{2}{|c|}{ Content, $\%$} & \multicolumn{2}{|c|}{ Gluten quality } & $\begin{array}{c}\text { Complex } \\
\text { index of } \\
\text { genotype } \\
\text { selection } \\
\text { value }\end{array}$ \\
\hline Katepwa & 33.6 & 799 & 80 & 14.8 & 35.8 & 74.1 & I & 0.543 \\
\hline Laval 19 & 38.4 & 724 & 9 & 13.3 & 28.2 & 72.9 & I & 0.049 \\
\hline Bluesky & 46.0 & 784 & 85 & 14.1 & 29.9 & 75.1 & I & 1.087 \\
\hline Wildcat & 40.9 & 773 & 67 & 16.3 & 39.2 & 84.9 & II & 0.222 \\
\hline Laura & 30.6 & 802 & 89 & 16.4 & 38.2 & 68.3 & I & 0.623 \\
\hline Glenlea & 44.5 & 779 & 84 & 14.7 & 34.5 & 77.2 & II & 0.679 \\
\hline Leader & 29.0 & 745 & 91 & 15.7 & 35.5 & 89.3 & II & 0.206 \\
\hline Zlata & 43.9 & 795 & 88 & 14.4 & 33.0 & 79.0 & II & 1.040 \\
\hline Oslo & 36.4 & 738 & 89 & 15.3 & 34.8 & 82.0 & II & 1.839 \\
\hline Biggar & 37.7 & 777 & 67 & 13.8 & 30.7 & 78.1 & II & 1.784 \\
\hline BW 90 & 38.3 & 792 & 96 & 16.2 & 38.0 & 79.0 & II & 1.982 \\
\hline Ac Barrie & 33.7 & 802 & 97 & 14.8 & 33.3 & 71.0 & I & 0.318 \\
\hline $\begin{array}{c}\text { Ac } \\
\text { Karma }\end{array}$ & 39.1 & 787 & 76 & 12.8 & 28.8 & 81.0 & II & 0.820 \\
\hline $\begin{array}{c}\text { CDC } \\
\text { Merlin }\end{array}$ & 36.1 & 792 & 93 & 15.1 & 32.2 & 69.3 & I & 1.489 \\
\hline Ac Taber & 42.1 & 808 & 91 & 13.7 & 29.8 & 70.0 & I & 1.266 \\
\hline LSD 05 & 2.6 & 32 & 18 & 0.5 & - & - & - & - \\
\hline
\end{tabular}


According to the classification of soft wheat varieties by baking value by E.M. Belousova, excellent improvers should contain protein - above $16 \%$, gluten - above $32 \%$ and GDI values in the range of 45-75 GDI units [8]. This group includes the Laura and BW 90 varieties. Good improvers should contain protein - above $15 \%$, gluten - above $30 \%$ and GDI values in the range of 45-75 GDI units. This group includes the CDC Merlin variety. Satisfactory improvers should contain protein - above $14 \%$, gluten - above $28 \%$ and GDI values in the range of 45-75 GDI units. This group includes the varieties Katepwa, Bluesky, Ac Barrie and Ac Taber. The varieties that are most valuable in quality should contain protein - above 13\%, gluten - above $25 \%$ and GDI values in the range of 45-85 GDI units. This group includes the most studied varieties - Laval 19, Wildcat, Glenlea, Leader, Zlata, Oslo, Biggar, Ac Kagma.

Thus, the studied Canadian varieties of spring wheat in terms of protein and gluten quality can be attributed either to the group of strong wheat (Laura, BW 90, CDC Merlin, Katepwa, Bluesky, Ac Barrie and Ac Taber), or the most valuable (Laval 19, Wildcat, Glenlea, Leader, Zlata, Oslo, Biggar, Ac Kagma).

Without exception, all Canadian wheat varieties significantly exceeded the Zlata standard in terms of the volume yield of bread, as well as its quality characteristics smooth, ruddy crust, pleasant white crumb, its fine-pored structure (Fig. 3, 4), very pleasant taste and aroma.

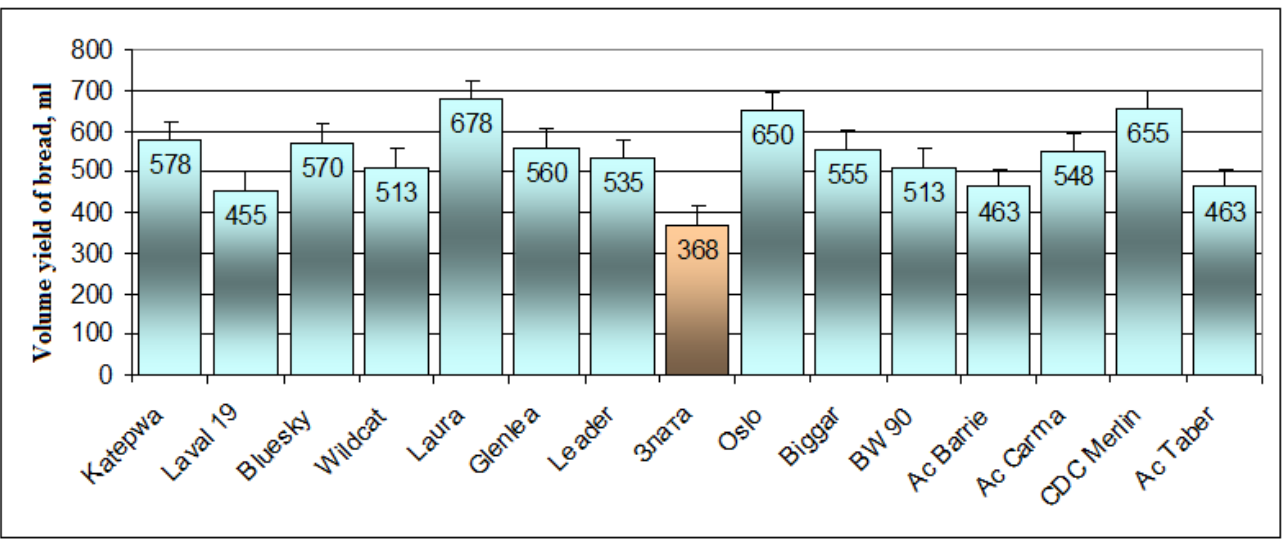

Fig. 3. Volume yield of bread value of the Canadian spring wheat collection

The maximum values of the volume yield of bread, significantly exceeding the values of the other varieties, were in the varieties Laura, Oslo, CDC Merlin (Fig. 3). The varieties Ac Barrie and Ac Taber gave a relatively low volume yield, but the organoleptic characteristics of the bread value were excellent. Perhaps they required a more intensive kneading or a longer time of proofing dough than for other varieties.

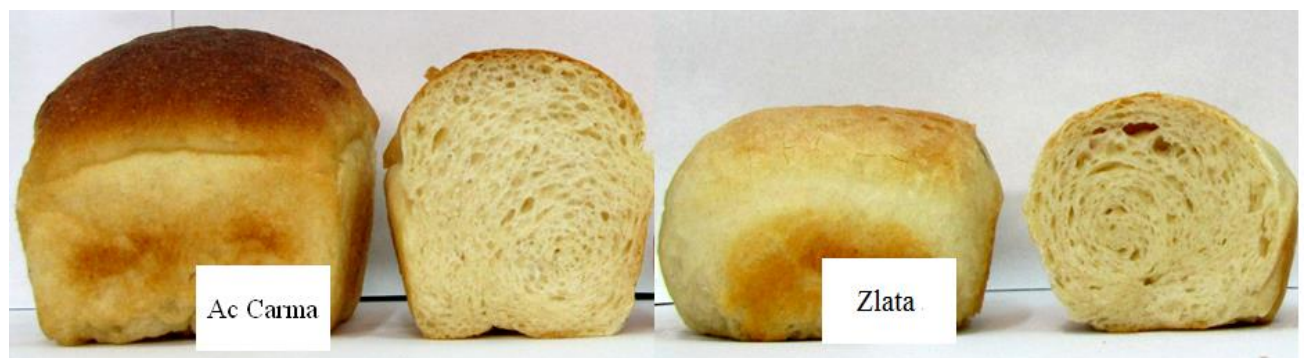

Fig. 4. Bread made from Canadian Ac Kagma flour and Zlata standard flour 
The correlation analysis of the conjugacy of the characteristics of the studied set of Canadian varieties showed that there is a significant positive relationship between the yield, the weight of 1000 grains and the unit, while there is a negative relationship between the yield and the indicators of baking value, although not everywhere reliable (Table 4). Grain size is negatively associated with its protein content and, accordingly, with baking value. Grain unit is positively correlated with vitreosity, which, in turn, is positively related to the biochemical qualities of the grain. The protein and gluten content are almost linear, and both positively correlate with the volume yield of bread. The presence of these relationships is revealed by many studies on different crop groups [12, 15, 17].

Thus, the breeder, increasing the values of some indicator, inevitably faces the presence of difficult-to-overcome conjugate relationships between the traits. Therefore, it is impractical to strive to obtain varieties with the maximum values of all economically useful traits. It is better to find some compromise, for example, an average yield with high values of stability and baking value. However, according to B.I. Sandukhadze, N.N. Likhenko, M.A. Khudenko et al., it is possible to combine high yield with high grain quality in the Central Non-Chernozem region $[13,15,16]$.

The analysis showed that all the studied varieties of the Canadian collection can be used in breeding for improved bread value. However, during the study, we saw a diversity of characteristics of these varieties according to other economically useful traits (Table 4). It is difficult to make an unambiguous choice. Moreover, when creating new varieties, they tend to get forms with a minimum number of negative traits. Therefore, the index method was used to identify the most valuable source material for breeding.

Table 4. Correlation between the characteristics and properties of the wheat collection

\begin{tabular}{|c|c|c|c|c|c|c|}
\hline & & & & & \multicolumn{2}{|c|}{ Content } \\
Indicators & $\begin{array}{c}\text { Yield, } \\
\mathrm{g} / \mathrm{m}^{2}\end{array}$ & $\begin{array}{c}\text { Weight } \\
\text { of } 1000 \\
\text { grains, } \\
\mathrm{g}\end{array}$ & $\begin{array}{c}\text { Unit, } \\
\mathrm{g} / \mathrm{l}\end{array}$ & $\begin{array}{c}\text { Common } \\
\text { vitreosity, } \%\end{array}$ & $\begin{array}{c}\text { protein, } \\
\%\end{array}$ & $\begin{array}{c}\text { raw gluten, } \\
\%\end{array}$ \\
\hline Yield, g/m $\mathrm{m}^{2}$ & & & & & & \\
\hline $\begin{array}{c}\text { Weight of 1000 } \\
\text { grains, g }\end{array}$ & $0.573^{*}$ & & & & & \\
\hline Unit, g/1 & 0.442 & 0.123 & & & & \\
\hline $\begin{array}{c}\text { Common } \\
\text { vitreosity, \% }\end{array}$ & -0.203 & -0.120 & $0.611 *$ & & & \\
\hline $\begin{array}{c}\text { Protein content, } \\
\%\end{array}$ & $-0.565^{*}$ & -0.418 & 0.067 & 0.429 & & \\
\hline $\begin{array}{c}\text { Raw gluten } \\
\text { content, \% }\end{array}$ & -0.473 & -0.369 & 0.131 & 0.398 & $0.943 * *$ & \\
\hline $\begin{array}{c}\text { Volume yield } \\
\text { of bread, ml }\end{array}$ & -0.441 & -0.392 & -0.034 & 0.240 & 0.353 & 0.271 \\
\hline
\end{tabular}

Its essence is as follows. For each variety, private indexes are calculated (index I): Index I = value of trait in variety / arithmetic mean of trait for all varieties. The complex (general) Ik indices for these varieties are obtained by multiplying the private indices. An increase or decrease in any of the private indices is reflected in the product, respectively. The highest products give an idea of the best wheat variety by a set of traits $[11,19]$.

To calculate the complex indices for the studied set of wheat varieties, we used private indices for the following traits: yield, height, resistance to lodging, brown rust, powdery mildew, fusarium head blight, weight of 1000 grains, grain unit, vitreosity, protein and gluten content, volume yield of bread (Tables 2, 3).

According to the results of the index evaluation, the varieties whose index was close to or higher than the standard value were distinguished - Bluesky, Oslo, Biggar, BW 90, Ac 
Kagma, CDC Merlin, Ac Taber. They are recommended to be used in the breeding of varieties with high yield and baking value of grain to obtain high-quality bread for a healthy diet of people. The successful use of the index method for evaluating the source material, as well as the breeding numbers, was shown in the studies of V.A. Mihkelman and V.V. Voronchikhin [11, 19].

\section{Conclusions}

Varieties of the Canadian breeding Oslo, Biggar, Ac Barrie, Ac Kagma have a very short growing season and can be used in breeding for early maturity. Samples of Katepwa, Laval 19, Wildcat, Oslo, Ac Barrie, Ac Taber have a strong stem and high resistance to lodging. The varieties Oslo, Biggar and Ac Taber are characterized by complex resistance to lodging and major fungal diseases in Central Russia. Canadian varieties are unsuitable for use in breeding for high yields in the conditions of the Central part of Russia. Thus, the studied Canadian varieties of spring wheat (Laura, BW 90, CDC Merlin, Katepwa, Bluesky, Ac Barrie and Ac Taber) in terms of protein and gluten quality can be attributed either to the group of strong wheat. The varieties Laval 19, Wildcat, Glenlea, Leader, Zlata, Oslo, Biggar, Ac Kagma - to the group of the most valuable in quality. The varieties Bluesky, Oslo, Biggar, BW 90, Ac Kagma, CDC Merlin and Ac Taber showed the highest values of complex indices. They are recommended for use in the breeding of varieties with high yield and baking value of grain.

\section{References}

1. R-M. Tamba-Berehoiu, S. Cristea, N. Mioara, Romanian Biotechnological Letters, 24(3), 522-530 (2019) DOI: $10.25083 / \mathrm{rbl} / 24.3 / 522.530$

2. N.S. Berkutova, Methods of assessment and grain quality formation, 206 (1991)

3. R. Różyło, J. Laskowski, Polish Journal of Food and Nutrition Sciences, 61(1), 55-62 (2011) DOI: 10.2478 / v10222-011-0006-8

4. N.S. Berkutova, O.A. Buko, Evaluation and selection of grain crops for resistance to germination in the ear: review, 59 (1982)

5. L.I. Dolgodvorova, V.V. Pylnev, Breeding of field crops for quality, 256 (2018)

6. Yu.B. Konovalov, General plant breeding, 480 (2013)

7. State Standards of the USSR. Seeds of agricultural crops. Methods for quality determination P. II. Official publication, 415 (1991)

8. V.V. Pylnev, Yu.B. Konovalov, T.I. Khupatsaria, Workshop on Field Crop Breeding and Seed Production, 448 (2014)

9. Methods of state variety testing of agricultural crops, Technological assessment of grain, cereals and legumes, 122 (1988)

10. B.A. Armor, Methodology of field experience, 238 (1979)

11. V.V. Voronchikhin, V.V. Pylnev, V.S. Rubets, I.N. Voronchikhina, Bulletin of the Kursk State Agricultural Academy, 7, 92-100 (2019)

12. R.I. Belkina, T.S. Akhtarieva, D.I. Kucherov, M.I. Maslenko, A.A. Savchenko, K.V. Moiseeva, Productivity and quality of spring soft wheat in the Northern Trans-Urals, 188 (2017)

13. N.N. Likhenko, The study of the source material content for spring soft wheat breeding on the quality of grain in the northern forest-steppe of Western Siberia, 15 (2006) 
14. L.G. Kurasova, Yu.Yu. Bandurina, Vavilov Readings, 84-86 (2019)

15. B.I. Sandukhadze, M.I. Rybakova, Z.A. Morozova, Scientific bases of winter wheat breeding in the Non-Chernozem zone of Russia, 426 (2003)

16. M.A. Khudenko, Comparative characteristics of samples of spring triticale of the VIR collection in the Conditions of the Krasnoyarsk forest-steppe, 17 (2014)

17. D.V. Pushkarev, Evaluation of spring soft wheat varieties for ecological plasticity and stability of grain yield, 15 (2018)

18. V.L. Kretovich, Biochemistry of grain and bread, 129 (1991)

19. V.A. Mihkelman, Methods for optimizing the technology of the breeding process of spring barley, 68 (2020) 